\title{
Digestive development of the early-weaned pig
}

\section{Effect of level of food intake on digestive enzyme activity during the immediate post-weaning period}

\author{
BY D. KELLY ${ }^{1 *}$, J. A. SMYTH ${ }^{2}$ AND K. J. MCCR ACKEN ${ }^{1,3}$ \\ ${ }^{1}$ Department of Food and Agricultural Chemistry, The Queen's University of Belfast, \\ Newforge Lane, Belfast BT9 5PX \\ ${ }^{2}$ Veterinary Research Laboratory, Stoney Road, Stormont, Belfast BT4 3SD \\ ${ }^{3}$ Food and Agricultural Chemistry Research Division, Department of Agriculture for Northern \\ Ireland, Newforge Lane, Belfast BT9 $5 P X$
}

(Received 25 January 1990-Accepted 21 June 1990)

\begin{abstract}
Gastric intubation was adopted as a means of comparing the effect of two feeding levels, continuous nutrient supply $(C)$ and restricted nutrient supply $(R)$, on the digestive development of pigs weaned at $14 \mathrm{~d}$ of age, during the first $5 \mathrm{~d}$ post-weaning. The absolute weights of the stomach and the pancreas were significantly greater $(P<0.001)$ in $C$ compared with $R$ pigs. The effect was not significant for pancreas weight when expressed per $\mathrm{kg}$ body-weight but was significant $(P<0.05)$ for stomach weight. The weights of the small intestine (SI), SI mucosa and total mucosal protein were significantly higher $(P<$ 0.001 ) in $C$ pigs but protein content per $g$ mucosa was similar in the $C$ and $R$ groups. There was no significant effect of treatment on the activity of lactase ( $\beta$-glucosidase; $E C$ 3.2.1.23) or sucrase (sucrose- $\alpha$-glucosidase; $E C$ 3.2.1.48) irrespective of the basis of comparison used. The specific activity ( $\mu \mathrm{mol} / \mathrm{min}$ per $\mathrm{g}$ protein) of maltase ( $\alpha$-glucosidase; $E C$ 3.2.1.20) and of glucoamylase (glucan-1,4- $\alpha$ glucosidase; $E C$ 3.2.1.3) were similar in $C$ and $R$ groups but activities of maltase ( $\mu \mathrm{mol} / \mathrm{g}$ mucosa) $(P<0.05)$, and maltase and glucoamylase $(\mathrm{mol} / \mathrm{d})(P<0.01)$ were significantly higher in $\mathrm{C}$ pigs. Villous height and crypt depth were significantly greater in $C$ pigs $(P<0.001$ and $P<0.05$ respectively). Enteroglucagon was significantly $(P<0.05)$ higher in $C$ compared with $R$ pigs. Xylose absorption and the digestibility of energy were not affected by treatment. Digestibility of dry matter, organic matter, crude protein (nitrogen $\times 6.25)$ and carbohydrate were significantly higher $(P<0.001, P<0.01$, $P<0.05$ and $P<0.001$ respectively) in $R$ pigs compared with $C$ pigs but the differences were small, ranging from 1.3 to $2.5 \%$. These results demonstrate that (1) nutrient intake in the weaned pig affects the anatomy, morphology and function of the gut, (2) there is considerable 'spare capacity' for digestion of cereal-based diets even in pigs weaned at $14 \mathrm{~d}$ of age, (3) measurements in vitro of digestive function are of limited value unless supported by information in vivo on absorption/digestibility.
\end{abstract}

Digestive development: Digestive enzyme activity : Pig

During early post-natal life the pig undergoes a rapid transition in digestive function. Qualitative and quantitative alterations in digestive enzyme secretions occur. Some workers have remarked that the most pronounced increases in enzyme activity correspond to periods of enhanced dry-feed consumption (Bailey et al. 1956; Corring et al. 1978; Shields et al. 1980). Induction of specific digestive enzymes in response to substrate feeding has been observed in a number of animal species (Howard \& Yudkin, 1963; Deren et al. 1967; Rosenweig \& Herman, 1969; Nitsan et al. 1974). Bailey et al. (1956) suggested that dietary intake of substrate may influence the expression of substrate-specific enzymes in the young pig. Manners \& Stevens (1972) observed that baby pigs reared artificially on diets containing sucrose had higher specific sucrase (sucrose- $\alpha$-glucosidase; EC 3.2.1.48)

* Present Address: Rowett Research Institute, Greenburn Road, Bucksburn, Aberdeen AB2 9SB. 
activity in the small intestine (SI) mucosa. McCracken (1984) noted a greater increase in maltase ( $\alpha$-glucosidase; EC 3.2.1.20) activity in pigs which consumed large quantities of cereal-based diets and Kelly et al. (1991) demonstrated marked induction of glucoamylase (glucan 1,4- $\alpha$-glucosidase, EC 3.2.1.3) by $3 \mathrm{~d}$ post-weaning when pigs received a cerealbased diet by gastric intubation.

The phenomena of poor feed consumption and growth check characteristic of the immediate post-weaning period have previously been considered to reflect the limited digestive and absorptive capacity of the young pig (Hampson, 1983). However, where feed is freely available, large individual variations in feed intake occur and it is impossible to determine the extent to which the digestive enzyme levels observed result from, rather than cause, poor feed intakes. Equally there is a lack of definitive evidence on the digestibility in vivo of diets in the immediate post-weaning period, apart from the reports of McCracken et al. (1980) and of McCracken \& Patterson (1980) who measured apparent digestibility between 5 and $10 \mathrm{~d}$ post-weaning in pigs weaned at $10 \mathrm{~d}$ of age.

The study of Kelly et al. (1991) used a level of nutrient intake intermediate to that normally observed in weaned pigs and one that is likely to occur in suckled pigs, but no attempt was made to measure apparent digestibility. The present experiment was designed to study the effects of post-weaning food intake on digestive enzyme development and the implications for digestive capacity in the weaned pig, using the technique of gastric intubation (Kelly et al. 1984), to control the pattern and amount of feed consumed.

The lower feeding level employed was typical of the intake observed in pigs given a pelleted diet to appetite and the higher feeding level was higher than that used in the previous study and close to the intake of suckled pigs.

\section{MATERIALS AND METHODS}

\section{Experimental treatments and management}

Pigs (36) obtained from the Agricultural Research Institute, Hillsborough, were selected from six litters (six pigs per litter) and precautions taken to equalize colostrum intake. At $14 \mathrm{~d}$ of age the pigs were allocated to one of two post-weaning treatments for $5 \mathrm{~d}: R$, restricted nutrient supply $(0,25,50,75,100 \mathrm{~g} / \mathrm{d}$ on day 1 to 5 respectively); C, continuous nutrient supply: litters 1 and $2(150,180,210,240,270 \mathrm{~g} / \mathrm{d}$ on day 1 to 5 respectively), litters 3-6 $(150,170,190,210,230 \mathrm{~g} / \mathrm{d})$.

Piglets were tube-fed a cereal-based diet (Kelly et al. 1991) six or seven times daily and feed consumption was accurately determined. A complete faeces collection was made on each animal during the $5 \mathrm{~d}$ experimental period. The samples were oven-dried, weighed, milled and stored in sealed containers before analysis.

On the morning of the 6th day post-weaning, an oral dose of D-xylose $(50 \mathrm{~g} / 1)$ was administered at 06.00 hours and blood samples collected $1 \mathrm{~h}$ later for determination of serum xylose concentration and fasting plasma enteroglucagon.

To obtain an accurate measure of apparent digestibility the total faecal dry matter output was corrected for the difference between the mean of the dry contents of the large intestine of pigs (SC) slaughtered at $14 \mathrm{~d}$ (Kelly et al. 1991) and for the contents in each individual animal determined at slaughter (EXP). Total feed digested during the $5 \mathrm{~d}$ period $=$ total feed consumed $-($ stomach contents $($ EXP $)-$ stomach contents $($ SC) $)-$ total faeces produced + (large intestine contents (EXP) - large intestine contents (SC)).

\section{Post-mortem procedure}

Pigs received their normal feed at 24.00 hours, and were tube-fed $40 \mathrm{~g}$ diet, $2 \mathrm{~h}$ before slaughter. Anaesthesia was induced using trichloroethylene and a midline laparotomy was 
Table 1. Organ weights and characteristics of small intestine (SI) mucosa in weaned pigs given continuous or restricted nutrient supply*

(Mean values for eighteen pigs; $24 \mathrm{df}$ )

\begin{tabular}{|c|c|c|c|c|}
\hline & Continuous & Restricted & SEM & $\begin{array}{c}\text { Statistical } \\
\text { significance: } \\
P=\end{array}$ \\
\hline \multicolumn{5}{|l|}{ Pancreas wt } \\
\hline (g) & $9 \cdot 75$ & $8 \cdot 15$ & 0.31 & $<0.001$ \\
\hline (g/kg BW) & $2 \cdot 07$ & 1.93 & 0.069 & 0.197 \\
\hline \multicolumn{5}{|l|}{ Stomach wt } \\
\hline (g) & $35 \cdot 1$ & $28 \cdot 4$ & $1 \cdot 19$ & $<0.001$ \\
\hline$(\mathrm{g} / \mathrm{kg} \mathrm{BW})$ & $7 \cdot 4$ & $6 \cdot 7$ & $0 \cdot 20$ & 0.022 \\
\hline \multicolumn{5}{|l|}{ SI wt } \\
\hline (g) & $191 \cdot 7$ & $127 \cdot 0$ & $6 \cdot 37$ & $<0.001$ \\
\hline$(\mathrm{g} / \mathrm{kg} \mathrm{BW})$ & $39 \cdot 0$ & $30 \cdot 0$ & $1 \cdot 13$ & $<0.001$ \\
\hline SI mucosa wt $(\mathrm{g})$ & $117 \cdot 2$ & $73 \cdot 6$ & $5 \cdot 35$ & $<0.001$ \\
\hline Total mucosal protein $(\mathrm{g})$ & $9 \cdot 5$ & $6 \cdot 2$ & $0 \cdot 45$ & $<0.001$ \\
\hline $\begin{array}{l}\text { Mucosal protein content } \\
(\mathrm{mg} / \mathrm{g})\end{array}$ & $84 \cdot 2$ & $84 \cdot 8$ & $2 \cdot 96$ & 0.871 \\
\hline
\end{tabular}

BW, body-weight.

* For details of feeding regimen, see p. 182.

Table 2. Weight of small intestine $(\mathrm{SI})$ mucosa $(\mathrm{g} / 100 \mathrm{~mm})$ at sites $1-5$ in weaned pigs given continuous or restricted nutrient supply*

\begin{tabular}{|c|c|c|c|}
\hline Site & Continuous & Restricted & Mean \\
\hline 1 & $2 \cdot 11$ & 1.76 & I.94 \\
\hline 2 & $2 \cdot 02$ & 1.55 & 1.78 \\
\hline 3 & $2 \cdot 31$ & 1.62 & 1.97 \\
\hline 4 & $2 \cdot 04$ & $1 \cdot 38$ & 1.71 \\
\hline 5 & $2 \cdot 09$ & 1.68 & 1.88 \\
\hline Mean & $2 \cdot 11$ & 1.60 & \\
\hline & $\begin{array}{c}\text { Statistical } \\
\text { significance }\end{array}$ & & \\
\hline & $P=$ & SEM & $\mathrm{df}$ \\
\hline Groups & $<0.001$ & 0.092 & 24 \\
\hline Sites & 0.029 & 0.065 & 116 \\
\hline Groups $\times$ sites & $0 \cdot 237$ & $0 \cdot 122$ & 116 \\
\hline
\end{tabular}

* For details of feeding regimen, see p. 182.

performed. Samples of SI and digestive organs were treated as described by Kelly et al. (1991).

\section{Digestive enzyme determinations}

The mucosa was removed from the partially thawed $100 \mathrm{~mm}$ lengths of SI and weighed. The mucosal scrapings were homogenized, centrifuged and the supernatant fraction diluted to an appropriate concentration. Enzyme and supernatant-fraction protein determinations were done as described by Kelly et al. (1991).

\section{Histology}

The samples of SI from sites 1, 3 and 5 were fixed in neutral-buffered formalin $(100 \mathrm{ml} / \mathrm{l})$ and processed by the standard paraffin method. Sections $(4-6 \mu \mathrm{m})$ were stained with 
Table 3. Mean values over five sites, for lactase (EC 3.2.1.23), sucrase (EC 3.2.1.48), maltase (EC 3.2.1.20) and glucoamylase (EC 3.2.1.3) activity (umol/min per g protein, $\mu \mathrm{mol} / \mathrm{min}$ per $g$ mucosa, mol/d) in the small intestine of weaned pigs given continuous or restricted nutrient supply*

(Mean values for eighteen pigs; $24 \mathrm{df}$ )

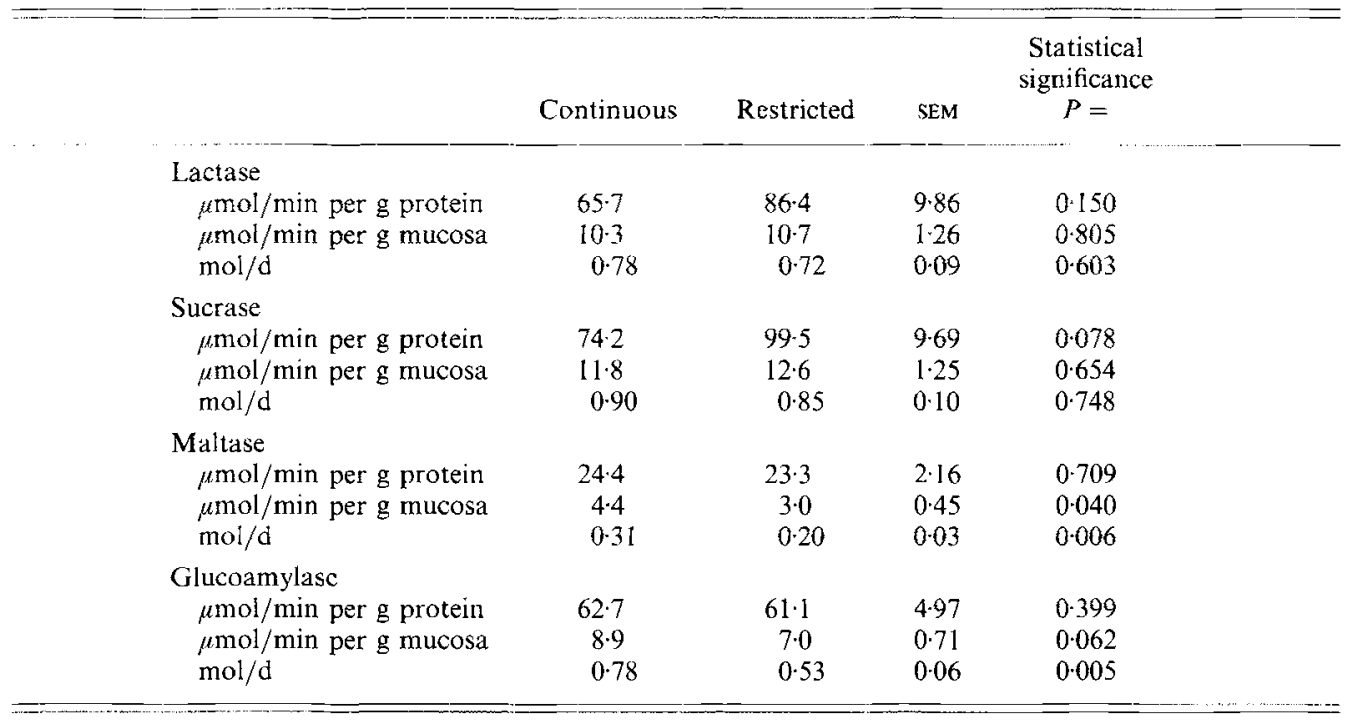

* For details of feeding regimen, see p. 182.

Table 4. Villous height and crypt depth at sites 1,3 and 5 of the small intestine of weaned pigs given continuous or restricted nutrient supply*

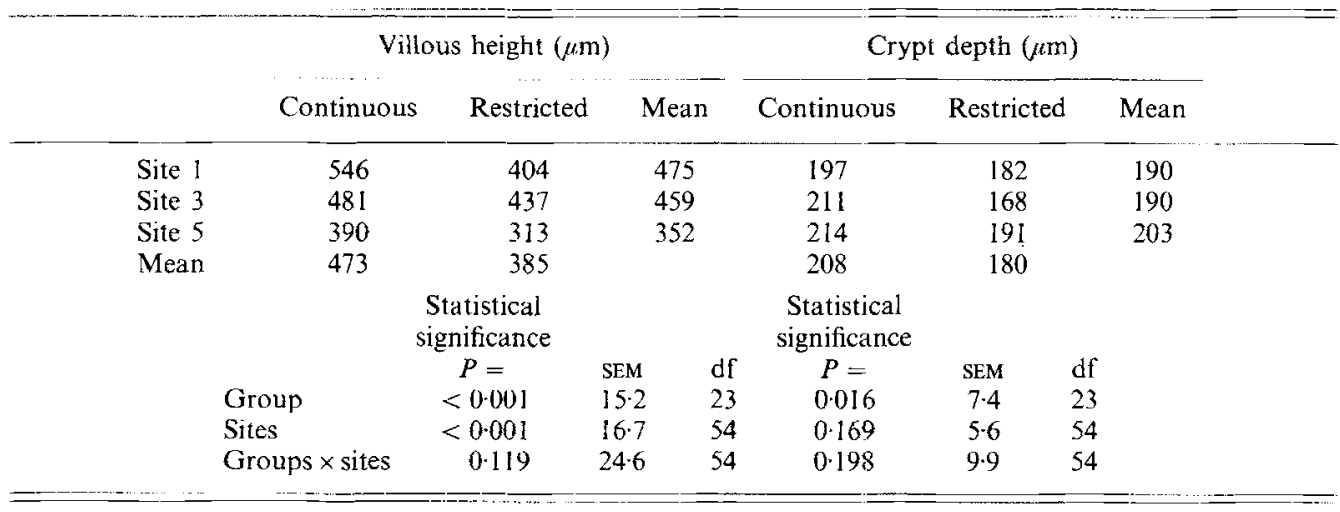

* For details of feeding regimen, see p. 182.

haematoxylin and eosin. Measurements of villous height and crypt depth were made on twenty to fifty well-orientated villi using an image analyser (Tasplus, Leitz Instruments).

Enteroglucagon and xylose determination

Blood samples for hormone analysis were collected in heparinized tubes. Plasma enteroglucagon concentration was measured by radioimmunoassay using two antisera of different specificity (Buchanan, 1973). The first, an $\mathrm{N}$-terminal reactive antibody (YY57), measures all known species of glucagon-like immunoreactivity extractable from the 
pancreas and gut. The other antibody, a C-terminal reactive antibody (YY89), is more specific for pancreatic enteroglucagon. $(\mathrm{N}-\mathrm{C})$-enteroglucagon is, therefore, a measure of gut hormone concentration.

For xylose absorption tests, pigs were orally dosed with $2 \mathrm{ml} / \mathrm{kg}$ body-weight of D-xylose $(50 \mathrm{~g} / \mathrm{l})$ and blood sampled $1 \mathrm{~h}$ later from the anterior vena cava. Serum xylose concentration was determined as described by Trinder (1975).

\section{Calculation and statistical analysis}

Total mucosa and mucosal protein weights were calculated from the mean values per $100 \mathrm{~mm}$ over the five sites and the SI length. Enzyme activities were expressed as specific activity (per g supernatant-fraction protein), per g mucosa or as total activity. The values presented for specific activity and per g mucosa are the means for the five sites. Total activity was calculated from the mean values per $100 \mathrm{~mm}$ over the five sites and the total SI length.

The results were subjected to analysis of variance using the Genstat package with litters being treated as a blocking factor. The enzyme results were analysed using a split-plot.

\section{RESULTS}

The mean dry matter intakes of $C$ and $R$ pigs were 864 and $226 \mathrm{~g}$ respectively and the corresponding mean weight changes were $+0.7 \mathrm{~kg}$ and $-0.1 \mathrm{~kg}$ over the feeding period. This difference was highly significant $(P<0.001)$. The animals remained healthy throughout the experiment and there were no overt signs of nutrient malabsorption at slaughter.

The weights of the stomach and pancreas were significantly higher $(P<0.001)$ in $\mathrm{C}$ pigs (Table 1). When expressed per $\mathrm{kg}$ body-weight, pancreas weight was not influenced by treatment but the $10 \%$ difference in stomach weight was significant $(P<0.05)$.

The mean weights of the SI and the SI mucosa were significantly higher in the continuous-fed animals $(P<0.001)$. When differences in body-weight were taken into account the SI weight of restricted pigs was only $77 \%$ of that of the $\mathrm{C}$ group $(P<0.001)$. The protein content per $\mathrm{g}$ mucosa was comparable in both weaned groups. However, the total protein content was greater in the $\mathrm{C}$ pigs $(P<0.001)$.

When the effect of treatment on the mucosal weight at individual sites of the SI was examined, the weight of mucosa per $100 \mathrm{~mm}$ SI was found to be consistently greater in piglets fed on the continuous nutrient supply (Table 2 ). The overall mean for the $\mathrm{R}$ group was only $75 \%$ of the $C$ value $(P<0.001)$.

In terms of specific activity none of the enzymes studied showed any significant treatment effects (Table 3), although lactase ( $\beta$-galactosidase; EC 3.2.1.23) and sucrase tended to be lower in the continuous-fed group. When expressed per g mucosa, maltase activity was higher for $\mathrm{C}$ pigs $(P<0.05)$ and the effect just failed to be significant for total glucoamylase. Total activities of lactase and sucrase were similar in both groups of weaned pigs. Total activities of maltase and of glucoamylase were higher $(P<0.01)$ in continuousfed pigs.

Villous height was consistentiy higher in $C$ pigs at the three sites examined (Table 4) and the effect was highly significant $(P<0.001)$. Similarly crypt depth was significantly increased $(P<0.05)$ in $\mathrm{C}$ pigs, the effect being most marked at site 3 .

The digestibility of energy was not significantly affected by treatment (Table 5). However, the coefficients for the digestibilities of dry matter and crude protein $(\mathrm{N} \times 6.25)$ were approximately $2.5 \%$ higher $(P<0.001$ and $P<0.05$ respectively) for the restrictedfed group. The differences between treatments were smaller for organic matter and carbohydrate digestibilities (1.9 and $1.4 \%$ respectively) but both effects were statistically significant $(P<0.01$ and $P<0.001)$. Blood xylose concentration was not significantly 
Table 5. Effect of continuous or restricted nutrient supply on the digestibility of dry matter $(D M)$, organic matter $(O M)$, crude protein $(C P)$, carbohydrate $(C H O)$ and energy, on xylose absorption and on $N$-, $C$ - and $(N-C)$-enteroglucagon in weaned pigs*

(Mean values for eighteen pigs; $24 \mathrm{df}$ )

\begin{tabular}{|c|c|c|c|c|}
\hline & Continuous & Restricted & SEM & $\begin{array}{c}\text { Statistical } \\
\text { significance } \\
P=\end{array}$ \\
\hline DM digestibility & 0.893 & 0.914 & 0.0042 & $<0.001$ \\
\hline OM digestibility & 0.910 & 0.927 & 0.0034 & 0.002 \\
\hline CP digestibility & 0.848 & $0 \cdot 871$ & 0.0072 & $0 \cdot 020$ \\
\hline CHO digestibility & 0.933 & 0.947 & $0-0025$ & $<0.001$ \\
\hline Energy digestibility & 0.898 & 0.904 & 0.005 & $0 \cdot 380$ \\
\hline Serum xylose $(\mathrm{mmol} / \mathrm{l})$ & 0.72 & 0.68 & $0 \cdot 080$ & $0-723$ \\
\hline $\mathrm{N}$-enteroglucagon (ng/l) & 1648 & 1053 & 156.6 & $0 \cdot 019$ \\
\hline C-enteroglucagon (ng/1) & 287 & 134 & $47 \cdot 6$ & $0 \cdot 041$ \\
\hline$(\mathrm{N}-\mathrm{C})$-enteroglucagon $(\mathrm{ng} / \mathrm{l})$ & 1360 & 920 & $147 \cdot 5$ & 0.055 \\
\hline
\end{tabular}

* For details of feeding regimen, see p. 182.

affected by the post-weaning feeding regimen. $\mathrm{N}$-terminal enteroglucagon and $\mathrm{C}$-terminal enteroglucagon concentrations were significantly higher $(P<0.05)$ in pigs given the continuous nutrient level but the difference just failed to be significant for $(\mathrm{N}-\mathrm{C})$ enteroglucagon.

\section{DISCUSSION}

The intake achieved in the $\mathrm{C}$ group by gastric intubation was higher than that used by Kelly et al. (1991) and considerably above voluntary intakes observed in the immediate postweaning period. The marked differences in final live weight between the $\mathrm{C}$ and $\mathrm{R}$ groups contributed to differences in the weight of different parts of the digestive tract. When considered relative to body-weight there was no significant treatment effect on pancreas weight whereas stomach and SI weight were both significantly higher in the $\mathrm{C}$ pigs. This demonstrates that there is an adaptive component of gut development associated with the amount of diet consumed. In relation to the SI, both the musculature and the SI mucosa were involved in the weight difference, the mucosa accounting for 61 and $58 \%$ of SI weight in $\mathrm{C}$ and $\mathrm{R}$ pigs respectively. At least part of the difference in the mucosa was attributable to the greater reduction in villous length in the $\mathrm{R}$ group from the values found in sowreared pigs (Kelly et al. 1991). Clearly these changes due to diet consumption must account for a considerable proportion of the variation observed in studies where intake was not controlled and emphasizes the benefits derived from controlling intake by gastric intubation.

Whereas feeding level did not significantly affect the activity of lactase or sucrase, maltase and glucoamylase, expressed on a total activity basis, significantly increased $(P<$ 0.01 ) in the C pigs compared with the R pigs. Smith et al. (1985) suggested that, during the weaning period, the changes in enzyme capacity of the villi are determined by two opposing phenomena, i.e. the distance along the villus where enzyme expression is initiated is reduced but the enterocytes are less mature when shed from the villi. The results for lactase and sucrase in the present study could be interpreted as consistent with this hypothesis. However, the longer villi in $C$ pigs coupled with the increase in the total activity of maltase and glucoamylase, which can be attributed entirely to the increase in mucosal protein in this group with no change in specific activity, are aspects which are not adequately accounted for by the hypothesis of Smith et al. (1985).

Determinations of lactase and sucrase specific activity have been assumed to provide an 
indication of digestive capacity in vivo (Kidder \& Manners, 1980; Hampson, 1983). Shields et al. (1980), Widdowson (1984) and Kelly et al. (1991) have suggested that total gut activity may be more meaningful. In the case of lactase and sucrase, if only specific activity had been measured, it would have been concluded that the high intake had caused an apparent reduction in enzyme activity. However, the problem arises of how to relate measurements in vitro to active uptake in vivo.

In the present experiment the values for total activity of lactase and sucrase were far in excess of those needed for the amounts of substrate consumed (intakes of approximately $20 \mathrm{~g}$ lactose and $10 \mathrm{~g}$ sucrose/d for $\mathrm{C}$ pigs). For glucoamylase, the values of 0.78 and $0.53 \mathrm{~mol} / \mathrm{d}$ for $\mathrm{C}$ and $\mathrm{R}$ pigs respectively would be more than adequate to hydrolyse the starch-derived maltoses assuming that the in vitro conditions used would equate to those pertaining in the gut. In view of the assumptions required it is clear that digestive enzyme activities, irrespective of the basis of expression, can only provide a crude assessment of digestive capacity. This view is supported by the study of Nir et al. (1973) who observed that nutrient digestibility was not changed over a wide range of digestive enzyme activity levels.

D-Xylose has been used to diagnose malabsorption resulting from pathological damage of the SI (Hill et al. 1970). The results of the present experiment illustrate that feeding level did not alter absorptive function as determined by xylose uptake. However, fasting enteroglucagon levels were significantly influenced by post-weaning treatment. Nutrients provide the stimulus for enteroglucagon release, and increasing levels have been correlated with mucosal hypertrophy and increased crypt cell production rate (Jacobs et al. 1976). Pigs fed on the continuous nutrient level had significantly higher levels of $(\mathrm{N}-\mathrm{C})$-terminal enteroglucagon. An increase in the amount of nutrient reaching the lower gut may have provided the stimulus for the release of this hormone (Utlenthal, 1985). The increases in weight of the SI, of SI mucosa and the greater villous height in the C group may have been attributable to the trophic effects of enteroglucagon, and enhanced secretion of this hormone may be the mechanism whereby gut function alters in response to the level of nutrient intake.

Although highly significant differences in apparent digestibility of dry matter, crude protein and carbohydrate were observed, actual differences were small and of an order which would not be detected by measurements of digestive enzyme activity or xylose absorption. This emphasizes the limitations of such approaches and the need for detailed nutritional balances to assist in interpreting the practical significance of changes in gut morphology and function. For example, Smith (1984) reported large reductions in the capacity in vitro of villi after weaning to transport amino acids, but recognized that the consequences of such a reduction would depend on the spare capacity of the gut to absorb nutrients. In the present study, despite the large food input by gastric intubation, the apparent digestibility of crude protein was only $2.5 \%$ lower in $\mathrm{C}$ pigs than in $\mathrm{R}$ pigs and the values were typical of the expected crude protein digestibility based on the dietary ingredients. Admittedly it is possible that a greater degree of hind-gut fermentation occurred in the $\mathrm{C}$ pigs and it would have been desirable to be able to measure ileal digestibility. The adopted method of calculation was an attempt to correct for this by measuring not just faecal output but large intestine contents at slaughter. Taking account of all the information presented here it is concluded that there is a considerable "excess capacity' for digestion in the weaned pig relative to the intakes normally observed in the immediate post-weaning period, and that assumptions about digestive capacity based on observations in vitro are of limited value.

In conclusion, these results demonstrate that (1) nutrient intake in the weaned pig affects the anatomy, morphology and function of the gut, (2) measurements in vitro of digestive function are of limited value unless supported by findings in vivo on absorption and 
digestibility and suggest (3) that, relative to intake, there may be considerable 'spare capacity' for digestion of cereal-based diets even in pigs weaned at $14 \mathrm{~d}$ of age.

D.K. was supported by a CAST Award from the Department of Education, Northern Ireland and John Thompson and Sons Ltd. The authors are indebted to Mr A. McAllister, Mr J. Lilley and MS L. Oliver for their expert technical assistance and to Dr D.J. Kilpatrick for statistical advice.

\section{REFERENCES}

Bailey, C. B., Kitts, W. D. \& Wood, A. J. (1956). The development of the digestive enzyme system of the pig during its pre-weaning phase of growth. Canadian Journal of Animal Science 36, 51-58.

Buchanan, K. D. (1973). Studies on the pancreatic-enteric hormones. PhD Thesis, The Queen's University of Belfast.

Corring, T., Aumaitre, A. \& Durand, G. (1978). Development of digestive enzymes in piglets from birth to 8 weeks. I. Pancreas and pancreatic enzymes. Nutrition and Metabolism 22, 231-243.

Deren, J. J., Broitman, S. A. \& Zamcheck, N. (1967). Effect of diet upon intestinal disaccharidases and disaccharide absorption. Journal of Clinical Investigation 46, 186-195.

Hampson, D. J. (1983). Post-weaning changes in piglet small intestine in relation to growth check and diarrhoea. PhD Thesis, University of Bristol.

Hill, F. W. G., Kidder, D. E. \& Frew, J. (1970). A xylose absorption test for the dog. Veterinary Research 87, 250-255.

Howard, F. \& Yudkin, J. (1963). Effect of dietary change upon the amylase and trypsin activities of the rat pancreas. British Journal of Nutrition 17, 281-294.

Jacobs, L. R., Polak, J., Bloom, S. R. \& Dowling, R. H. (1976). Does enteroglucagon play a trophic role in intestinal adaptation? Clinical Science and Molecular Medicine 50, 14p-15p.

Kelly, D., Green, J. A., O'Brien, J. J. \& McCracken, K. J. (1984). Gavage feeding of early-weaned pigs to study the effect of diet on digestive development and changes in intestinal microflora. Proceedings of VIIIth Internationat Pig Veterinary Society Congress, Ghent, p. 317 [M. Tensaert, J. Hoorens, P. H. Lampo, P. B. Onte, W. Coussement and P. Debonck, editors]. Casinoplein, Ghent, Belgium: Faculty of Veterinary Medicine, State University of Ghent.

Kelly, D., Smyth, J. A. \& McCracken, K. J. (1991). Digestive development of the early-weaned pig. I. Effect of continuous nutrient supply on the development of the digestive tract and on changes in digestive enzyme activity during the first week post-weaning. British Journal of Nutrition 65, 169-180.

Kidder, D. E. \& Manners, M. J. (1980). The level and distribution of carbohydrases in the small intestine mucosa of pigs from 3 weeks of age to maturity. British Journal of Nutrition 43, 141-153.

McCracken, K. J. (1984). Effect of diet composition on digestive development of early-weaned pigs. Proceedings of the Nutrition Society 43, 109A.

McCracken, K. J., Eddie, S. M. \& Walker, N. (1980). Effect of flaked maize in diets for early-weaned pigs on performance to 6 weeks of age. Animal Production 30, 85-94.

McCracken, K. J. \& Patterson, D. C. (1980). Utilization of skim milk based diets containing ground wheat by pigs weaned at $10 \mathrm{~d}$. Record of Agricultural Research 28, 99-102.

Manners, M. J. \& Stevens, J. A. (1972). Changes from birth to maturity in the pattern of distribution of lactase and sucrase activity in the mucosa of the small intestine of pigs. British Journal of Nutrition 28, 113-127.

Nir, I., Nitsan, Z. \& Vax, A. (1973). The influence of force-feeding and of protein supplementation to the diet on the metabolisable energy of diets, digestibility of nutrients, nitrogen retention and digestive enzyme output in geese. Annals de Biologie Animale, Biochimie, Biophysique 13, 465-479.

Nitsan, Z., Dror, Y., Nir, I. \& Shapira, N. (1974). The effect of force-feeding on enzymes of the liver, kidney, pancreas and digestive trace of chicks. British Journal of Nutrition 32, 241--247.

Rosensweig, N. S. \& Herman, R. H. (1969). Diet and disaccharides. American Journal of Clinical Nutrition 22, 99102.

Shields, R. G., Ekstrom, K. E. \& Mahan, D. C. (1980). Effect of weaning age and feeding method on digestive enzyme development in swine from birth to 10 weeks. Journal of Animal Science 50, 257-265.

Smith, M. W. (1984). Effect of post-natal development and weaning upon the capacity of pig intestinal villi to transport alanine. Journal of Agricultural Science, Cambridge 102, 625-633.

Smith, M. W., Miller, B. G., James, P. S. \& Bourne, F. J. (1985). Effect of weaning on the structure and function of piglet small intestine. Proceedings of 3rd International Seminar on Digestive Physiology in the Pig, Copenhagen, pp. 75-78 [A. Just, H. Jorgenson and J. A. Fernandez, editors]. Landhusholdningsselkskabets Forlag: Trykt i Frederiksberg Bogtrykkeri.

Trinder, P. (1975). Micro-determination of xylose in plasma. Analyst 100, 12-15.

Utlenthal, L. D. (1985). The gut hormone response to food. Proceedings of the Nutrition Society 44, 53-61.

Widdowson, E. M. (1984). Milk and the newborn animal. Proceedings of the Nutrition Society 43, 87-100. 